inhibitors (baricitinib and tofacitinib, respectively), one patients with antiTNF (infliximab) and another one with anti-CD20 (rituximab).

Conclusion: In general, our results match with what it is published in the literature.

For the treatment of AOSD has been used high doses of ASA (4g/day) or NSAID. However, the required doses (with their respective adverse effects), its limited responses and the frequent relapses after its suppression make difficult to maintain it. Nowadays, the systemic glucocorticoids are our first choice $(0,5$ to $1 \mathrm{mg} / \mathrm{kg} /$ day). A high average of our patients have a positive response with it, but in a $54 \%$ of the cases were neccesary to add methotrexate or others DMARDs because of a partial response with steroids.

In the physiopathology of the AOSD there is an increase of pro-inflammatory cytokines, as the tumor necrosis factor, IL-1 e IL-6. The use of therapies that inhibit these molecules (anti-TNF, anakinra or canakinumab as anti-IL1 or tocilizumab or sarilumab as anti IL-6) is being a progress. The inhibitors of IL-1 can be more efficient for systemic manifestations, while the inhibitors of IL-6 are for articular and systemic affectation. The TNF inhibitors should being used for the articular affectation only. In our patient cohort there is no patient with anti-IL1, a patient in clinical remission with anti-TNF and another one with anti-IL-6. Prospective studies with a higher number of patients is neccesary to define better the AOSD treatment.

Disclosure of Interests: None declared

DOI: 10.1136/annrheumdis-2019-eular.4904

\section{AB1077 ANTI-IL6-RECEPTOR TOCILIZUMAB IN GRAVES' ORBITOPATHY. MULTICENTER STUDY OF 46 PATIENTS IN CLINICAL PRACTICE}

Belén Atienza-Mateo ${ }^{1}$, José Luis Martín-Varillas ${ }^{1}$, Vanesa Calvo-Río ${ }^{1}$, Rosalía Demetrio-Pablo ${ }^{1}$, Elia Valls-Pascual ${ }^{2}$, Beatriz Valls-Espinosa ${ }^{2}$, Olga MaizAlonso $^{3}$, Ana Blanco ${ }^{3}$, Ignacio Torre-Salaberri ${ }^{4}$, Verónica Rodriguez-Mendez ${ }^{4}$, Ángel García-Aparicio ${ }^{5}$, Raúl Veroz González ${ }^{6}$, Vega Jovani ${ }^{7}$, Diana Peiteado ${ }^{8}$, Margarita Sanchez Orgaz ${ }^{8}$, Santos Castañeda' ${ }^{9}$, Eva Tomero ${ }^{9}$, J Francisco. Toyos Sáenz de Miera ${ }^{10}$, Valvanera Pinillos ${ }^{11}$, Elena Aurrecoechea ${ }^{12}$, Ángel Mora $^{12}$, Arantxa Conesa ${ }^{13}$, Manuel Fernández ${ }^{14}$, J. Antonio Troyano ${ }^{15}$, Iñigo GonzálezMazón ${ }^{16}$, Lara Sánchez Bilbao ${ }^{16}$, D. Prieto-Peña ${ }^{16}$, Monica Calderón-Goercke ${ }^{16}$ Miguel Á. González-Gay ${ }^{1}$, Ricardo Blanco ${ }^{1} .{ }^{1}$ Hospital Universitario Marqués de Valdecilla. IDIVAL., Rheumatology and Ophthalmology, Santander, Spain; ${ }^{2}$ Hospital Peset, Rheumatology, Valencia, Spain; ${ }^{3}$ Hospital Universitario de Donostia, Rheumatology and Ophthalmology, San Sebastián, Spain; ${ }^{4}$ Hospital Universitario de Basurto, Rheumatology and Ophthalmology, Bilbao, Spain; ${ }^{5}$ Hospital Virgen de la Salud, Rheumatology, Toledo, Spain; ${ }^{6}$ Hospital de Mérida, Rheumatology, Mérida, Spain; ${ }^{7}$ Hospital General de Alicante, Rheumatology, Alicante, Spain; ${ }^{8}$ Hospital Universitario La Paz, Rheumatology and Ophthalmology, Madrid, Spain; ${ }^{9} \mathrm{Hospital}$ de La Princesa, Rheumatology, Madrid, Spain; ${ }^{10} \mathrm{Hospital}$ Universitario Virgen Macarena, Rheumatology, Sevilla, Spain; ${ }^{11}$ Hospital San Pedro, Rheumatology, Logroño, Spain; ${ }^{12}$ Hospital Sierrallana, Rheumatology and Ophthalmology, Torrelavega, Spain; ${ }^{13}$ Hospital Clínico Universitario de Valencia, Rheumatology, Valencia, Spain; ${ }^{14}$ Hospital Universitario de Guadalajara, Rheumatology, Guadalajara, Spain; ${ }^{15}$ Hospital Universitario Clínico San Carlos, Rheumatology, Madrid, Spain; ${ }^{16}$ Hospital Universitario Marqués de Valdecilla. IDIVAL., Rheumatology and Ophthalmology, Santander, Spain

Background: Graves' orbitopathy (GO) is the most common and important extrathyroidal manifestation of Graves' disease. Corticostereoids and conventional immunosuppressors are not always effective or well tolerated. The IL-6 receptor antibody tocilizumab (TCZ) has demonstrated efficacy in the treatment of this pathology.

Objectives: To assess the efficacy of TCZ in refractory thyroid associated orbitopathy (TAO) due to Grave's disease.

Methods: Multicenter study of 46 patients with TAO refractory to conventional immunosuppressive therapy.

Results: We studied 46 patients (85 eyes) (37 women/9 men); mean age at diagnosis $49.2 \pm 11.8$ years. Besides oral corticosteroids, before the onset of TCZ patients had been treated with pulses of iv methylprednisolone (42), radioactive iodine (4), methotrexate (2) and other drugs (selenium in 11 cases, methimazole in 8, leflunomide in 1 and azathioprine in 1). 7 patients underwent ocular urgent decompressive surgery.

According to the classification of severity of the EUGOGO group (European Group on Graves' Orbitopathy) using the clinical activity score (CAS), before TCZ onset patients whose data were available had severe (27 eyes) or moderate (34 eyes) disease. Moreover, patients presented exophthalmos (53 eyes), strabismus (37 eyes), muscle fibrosis (38 eyes) and dysthyroid optic neuropathy (10 eyes).

TCZ was used in monotherapy (43) or combined with methotrexate (2) or azathioprine (1) at $8 \mathrm{mg} / \mathrm{kg} / \mathrm{iv} / 4 \mathrm{w}$ (41) or $162 \mathrm{mg} / \mathrm{sc} / \mathrm{w}$ (5). TCZ yielded rapid and maintained improvement in all ocular parameters as shown in Figures.

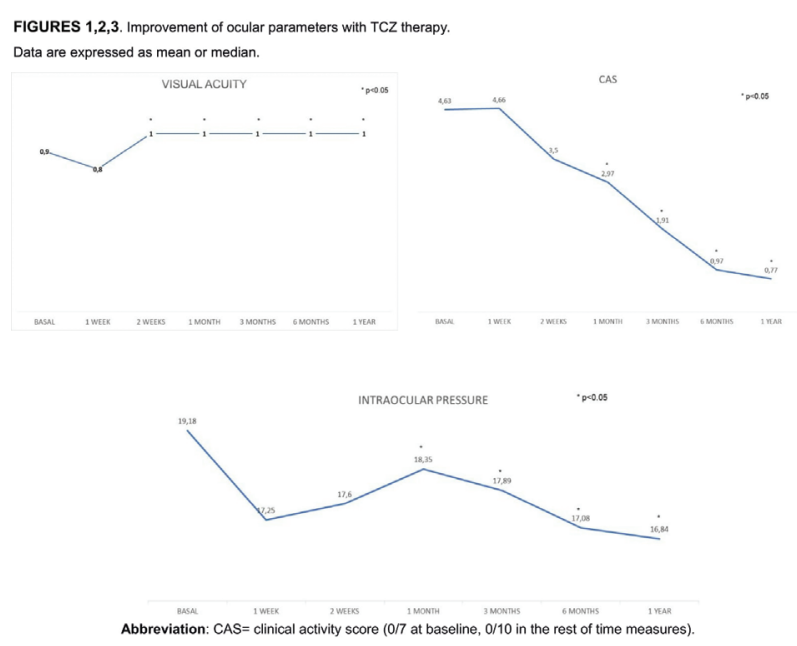

Figure 1

After a mean of $7.42 \pm 6.41$ months using TCZ and a mean follow-up of $16.47 \pm 11.99$ months, all patients experienced ocular improvement, with TCZ withdrawal in 28 cases due to complete remission (10), improvement (12) or stability of ocular inflammation (3), inefficacy (2) and total thyroidectomy (1). Only 5 relevant adverse effects were observed (neutropenia, external otitis, otitis media, costal osteitis and gingival hyperplasia, 1 each).

Conclusion: TCZ appears to be a useful and secure option in GO treatment.

\section{REFERENCES}

[1] Bartalena L, et al. Consensus statement of the European group on Graves' orbitopathy (EUGOGO) on management of Graves' orbitopathy. Thyroid. 2008; 18 (3:333-346).

[2] Russell DJ, et al. Tocilizumab as a steroid sparing agent for the treatment of Graves' orbitopathy. Am J Ophthalmol Case Rep. 2017 Jul 8;7:146-148.

Disclosure of Interests: Belén Atienza-Mateo: None declared, José Luis Martín-Varillas: None declared, Vanesa Calvo-Río: None declared, Rosalía Demetrio-Pablo: None declared, Elia Valls-Pascual: None declared, Beatriz Valls-Espinosa: None declared, Olga Maiz-Alonso Speakers bureau: Pfizer, Ana Blanco: None declared, Ignacio Torre-Salaberri: None declared, Verónica Rodriguez-Mendez: None declared, Ángel García-Aparicio: None declared, Raúl Veroz González: None declared, Vega Jovani: None declared, Diana Peiteado: None declared, Margarita Sanchez Orgaz: None declared, Santos Castañeda Consultant for: Amgen, BMS, Pfizer, Lilly, MSD, Roche, Sanofi, UCB, Eva Tomero: None declared, Francisco J. Toyos Sáenz de Miera: None declared, Valvanera Pinillos: None declared, Elena Aurrecoechea: None declared, Ángel Mora: None declared, Arantxa Conesa: None declared, Manuel Fernández: None declared, J. Antonio Troyano: None declared, Iñigo González-Mazón: None declared, Lara Sánchez Bilbao: None declared, D. Prieto-Peña: None declared, Monica Calderón-Goercke: None declared, Miguel Á. González-Gay: None declared, Ricardo Blanco: None declared DOI: 10.1136/annrheumdis-2019-eular.1628

\section{AB1078 RED CELL DISTRIBUTION WIDTH (RDW) - A NEW POSSIBLE DISEASE ACTIVITY PREDICTOR IN RELAPSING POLYCHONDRITIS}

Bianca Balan $^{1,1}$, Roxana loana Gutiu ${ }^{1}$, Felicia Mustățea ${ }^{1}$, Ioana Felea ${ }^{1}$, lleana Filipescu ${ }^{1}$, Cristina Pamfil ${ }^{1}$, Liliana Bene ${ }^{2}$, Simona Rednic ${ }^{1}$, Laura Damian¹. ${ }^{1}$ County Emergency Hospital Cluj-Napoca, Rheumatology, Cluj-Napoca, Cluj, Romania; ${ }^{2}$ County Emergency Hospital Cluj-Napoca, Immunology, Cluj-Napoca, Cluj, Romania

Background: Relapsing polychondritis (RP) is a rare condition defined by recurrent inflammation of cartilaginous tissue and systemic manifestations. Biomarkers for RP diagnosis and assessment of disease activity, damage and prognostic in clinical practice are currently lacking. Red blood cell distribution width (RDW) is an index of erythrocyte size variation depicting 